教育講座

\title{
外来診療におけるめまい診断・治療のポイント
}

竹山勇

\section{The Main Points of Diagnosing and Treating Patients with Vertigo and/or Equilibrium Disturbances}

\author{
Isamu Takeyama \\ Takeyama ENT Clinic \\ (Emeritus Professor St. Marianna University School of Medicine)
}

Recently, cases of vertigo have shown a tendency to increase, especially among middle age, and elderly patients. However, these patients often consult an internist or clinical neurogist. Therefore, I will touch upon the main points of diagnosing and treating patients with vertigo at an ENT clinic.

As an approach to diagnosis, first, taking the history plays a great role, secondly, neurological signs are useful for distinguishing peripheral and/or central vertigo. Next, from among the vestibular function tests available, examination of eye movements, spontaneous nystagmus include gaze nystagmus, positional and positioning nystagmus, head shaking nystagmus and stabilometry are significant.

In this paper, I report cases of vertigo or equilibrium disorders and discuss the treatment or prescription based on my clinical experience.

Generaly, ENT doctors should treat patients with vertigo.

Key words: taking of history, neurological signs, eye movements, head shaking nystagmus, stabilometry, peripheral vertigo, central vertigo

\section{はじめに}

めまい疾患は近年, 増加の傾向にあり，とくに 中高年層のめまい症例を取り扱らことが多い。し かし，めまいという疾患の背景因子が多様なため か，日本平衡神経科学会がめまい. 平衡障害の研 究と併せ, 診断や治療にも力を注ぎ一般臨床医の めまいに対する関心を高め，めまい症例を耳鼻科 医が取り扱らべき守備範囲であることの啓蒙も行 い, 平衡機能検査に対する保険点数の引き上げ

竹山耳鼻咽堠科クリニック

(聖マリアンナ医科大学 名誉教授)
や，新しい検査の保険適用などに努力してさた が，実地医家によるめまい症例は耳鼻科よりも一 般内科や神経内科訪九ている実状は残念化思わ れる。そこで今回は現場の耳鼻科医がめまい疾患 をより手軽に，上り手早く対応され，めまい平 衡障害が耳鼻科医の日常診療範囲の対象として取 り扱われることを願い, めまい診断・治療のポイ ソトを述べた。

ポイント I

めまいを大別して末梢性，中枢性に分け，中で も生命に関わる病態か否かの振り分けが大切であ る。 


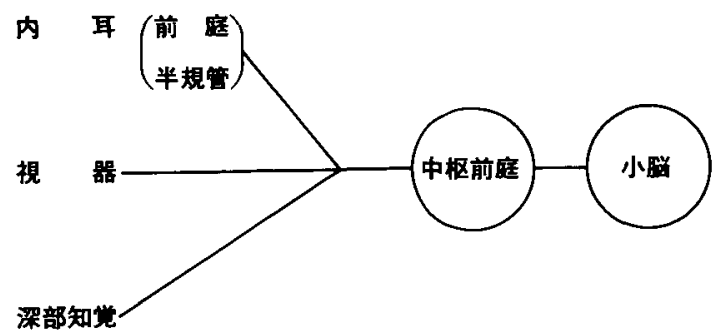

$\left(\begin{array}{l}\text { 新部 } \\ \text { 項部 }\end{array}\right.$ 恋神経系)

図1めまいの起こり方

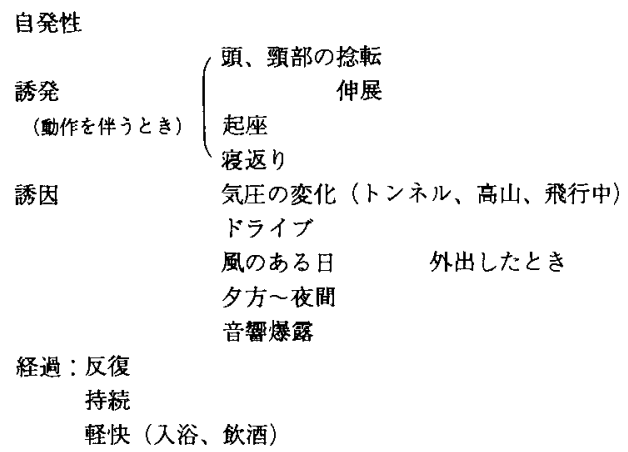

図3めまいの起こり方, 経過のチェック

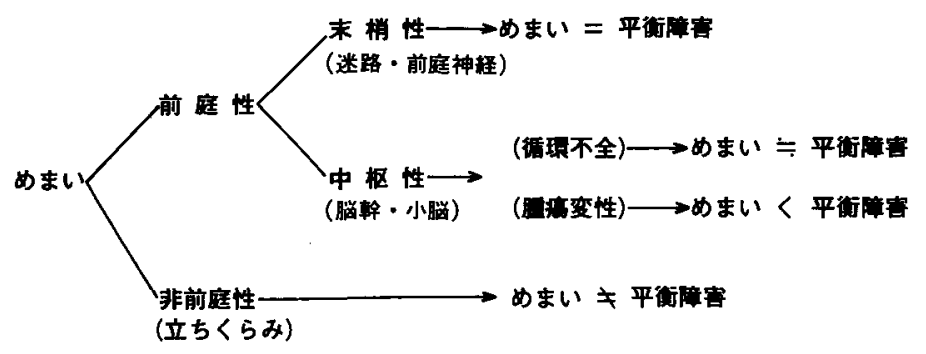

図 2 「めい」と「平衡障害」

めまいの起こり方をみると内耳及び視器や深部 知覚系の異常に基づく末梢性障害と, 脳幹, 小脳 あるいは大脳の障害による中枢性の病因に分けら れ（図 1)，めまい発作に伴い身体の平衡障害を 来すことも少なくない。めまいと平衡障害の関わ りをみてみると（図2），末梢性の場合ではめま いが烈しい時に平衡障害も注添同程度に強く，中 枢性の疾患ではめまい上りも平衡障害が強く前面 に出てくることもみられる。

ポイント II

病歴聴取・問診

めまい患者に対する外来診察に扣いては病歴聴 取に始まり神経学的検査, 聴力検查, 眼振検查と 進めてゆくのが一般的手順と思うが，めまい患者 の診察は患者の入室時から始まるもので，患者の 歩行状態, 顔色, 顔貌をチェックし, 歩行困難か 強度の失調症かといった平衡障害の程度を見分 け, 顔面の状熊からめまい感の強弱, 貧血の有無 も判別できる。対座して血圧測定, 脈搏, 呼吸数 などからバイターインをチェックし，次いで問 診に移るが，言語（発語）状態にも注意し，円滑
(1) めまい症状の確認

回転感

位置異常感

昇降感

酷酊感、浮動感、動嗳感

眼前暗黒感、脱力感、不安定感

沈む感し

倒れる感じ

(2) 副症状、随伴症状の確認

耳鸣、難聴（虾牛症状）

頭 浦

梘力障害

知賞・運動辟害

意識障害

図 $4 \mathrm{a}$ 問診の要点

な話し方か否かも判断する。問診票により，めま いの発生状況（起こり方，経過）など（図 3 ）を 一読したら，さらに要点を聞き出していく（図 4 $\mathrm{a}$ ，図 $4 \mathrm{~b})$ 。患者や家人に話をさせると時間もか かり，その人の知的レベルにも差があって要領の 得ないことも多いので，考觉られる病態の同定， 否定を中心とした聞き出し万が大切であり，時間 の無䭾も少ない。

病歴に招いてはめまいの性質, めまいの持続時 間，めまいの起こり方，めまいの経過と同時に随 伴症状，神経学的徵候（図 5 ）などの聴取を行い， また，外傷，交通事故，薬剤中毒の既往歴と併せ 家族歴も参考にしたい（図 6 )。

神経疾患の殆どは要点を得た病歴聴取や問診に より,ある程度の病態を診断することが可能であ るが，めをい疾患においても問猃は大切なポイン トの一つであり，問診内容から内耳性障害か中枢 
(3) めまい発現時の状況

運娌・スポーツのあと

入浴中, 入浴後

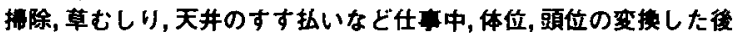

早朝 起床後

夕方 疲労後

興豈した後

かぜの後

(4) 病変部位の推定

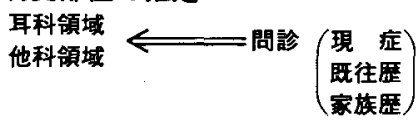

娭查

(5) 原因の推定

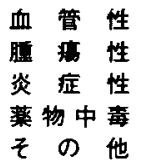

図 $4 b$

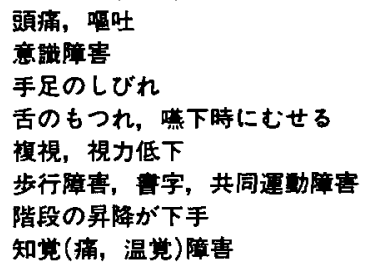

図 5 随伴症状，神経学的徵候

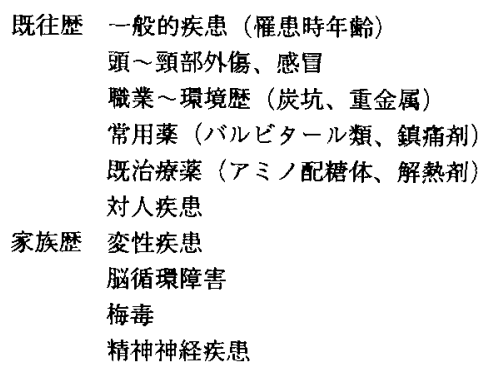

図 6 病歴聴取（既往歴，家族歴）の参考事項

性障害かを推定できる（図 7，8）。しかし，自覚 的症状としてめまいを訴えてもその背景に多様な 病態のあることも考慮し，めまい伴う異常反射 に留意すべきである（図 9 )。

ポイント III

検查のすすめ方

既述した問䛦に始まり，次いで検査に移るが
1. 擏しい回枟性めまい発作 自発性，反復性，可逆性

2.一側性の耳鳴, 孉聴, 耳門塞感が めまいと同時 あるいは発作に前 後して随伴する。

3. 步行㣂倚などは日中より夕方, 夜 間が强い。

4. ある頭位により「めまい」が誘発 されるが短時間で咸衰する。

5. VII鼡神経以外の神経症状が見当 らない

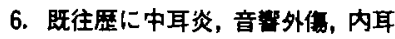
振滥、ストマイ注射,などがある。

図 7 内耳性障害を考兑させる問診内容

1.「めまい」随伴する蛞牛症状がない。

2. 神経症状を伴うことが多い。

a. 復視。顔面，口雪，四肢のシビレ感。

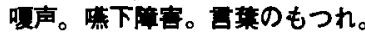

b. 浇しい頭室，けいれん，振せん， 意部险容などの合併。

3. 平衡等富が強い。

a. 倒れやすい。

b. 佶段を降りる時うまく歩けない。 㫒る時に力が入らない。

c.つまづき易い。スリッパが脱げる。 字が貫きにくい。

4. その他

a. 半身の感じが餴い。

b. 冷たい, 熱いの感触が鈍い。

c. 手足に力が入らない。

d. 視力，視里がおかしい。

図 8 中枢性障害を思わせる問診内容 


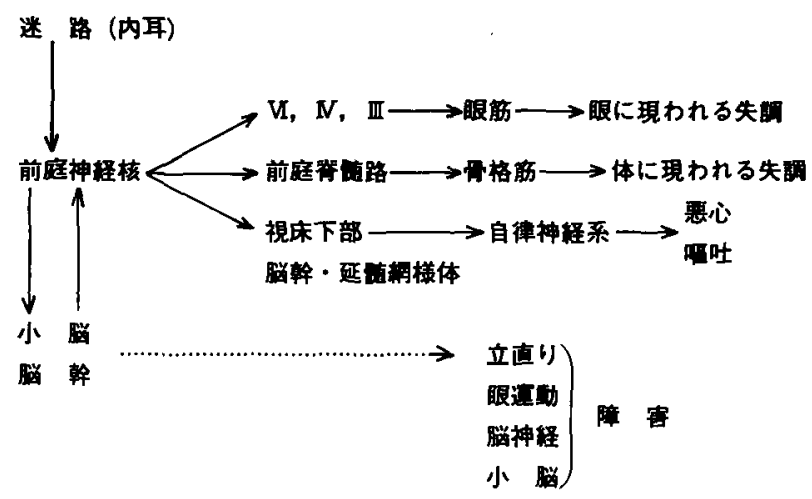

図 9 「めいいK伴ら異常反射

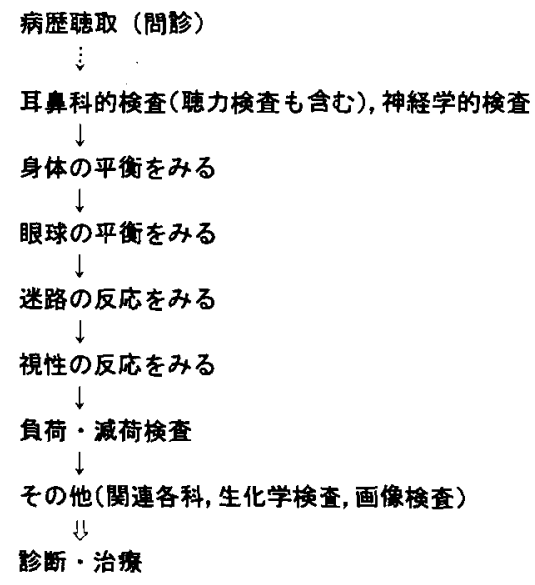

図10 検査のすすめ方

（図10），耳鼻科的検查（耳，鼻，㸶，喉検查）上 併せ脳神経症状，小脳症状の有無を確認寸る。耳 鼻科医にとっては身近にある診療器材の綿棒や舌 王子，喉頭鏡を用いれば顔面の知覚異常，角膜反 射，咽頭反射の状態や声帯運動の所見などと併せ 各脳神経症状のチェックはベットサイドにおいて 可能である。小脳症状の所見としては共同運動の 異常 (dyssynergia) が大切で，その代表的検査 として筆者は指鼻（あるいは指指）試験と手首の 回内, 回外運動に括ける拙少の程度 (adiadochokinesis）をチェックし，また Holmes-Stewart 現 象の陽性か否かを検查している。めまい，平衡障 害の検査に際しては，身体に現れる平衡障害と眼 に現れる平衡障害（眼振, 眼球の運動障害）とに 分けて検査することが大切である。身体に現れる
平衡障害として立直り，偏倚の異常を検查する方 法もあるが，多忙な日常診療では Mann 検査と 重心動摇検查で十分であるう。重心動摇検査に拉 いては体重心の摇らぎの変化を客観的に把六, 定 量的に分析することが可能であり，特徽的な動摇 パターンが示された場合には迷路性か中枢性平衡 障害, 中です小脳系, 答䯣反射系, 大脳基底系の 障害による平衡障害かの推定に役立つ（図11）。

眼に現れる平衡障害は眼球運動系の異常として 観察され，とくに眼振検查は多くの情報を提供し てくれる大切な検查法である。

眼球運動の検查

眼球の二点交互試験の便法として患者の眼前約 $30 \mathrm{~cm}$ に指をゆっくり左 $\rightarrow$ 右 $\rightarrow$ 左と左右に移動さ せ患者の眼球の追従運動に注意する。これは追従 眼球運動検查 (ETtest) に相当し, smooth pursuit eye movement が観察できる。すうつの方 法は指の移動を左 $\rightarrow$ 右 $\rightarrow$ 左に急速に行らおので, これは saccadeの検査として代用され, 眼球運 動の dysmetria (hypometria, hypermetria) の有 無が判定できる。

眼振の検查

各検査法の手技や所見の記載法は成畫に譲るが 前述の眼球運動の観察に続いて, 開眼下で注視眼 振の有無をチェックする。この際, 眼振の有無と 併せ，眼球運動の障害（注視麻痺）も観察する。 注視眼振の発現はめまい疾患の診断上大切であ り，中枢性障害の場合には左右方向への注視眼振 や注視麻瘏の所見もみられる。

自発眼振, 頭位眼振, 頭位変換眼振, 頭振り眼 


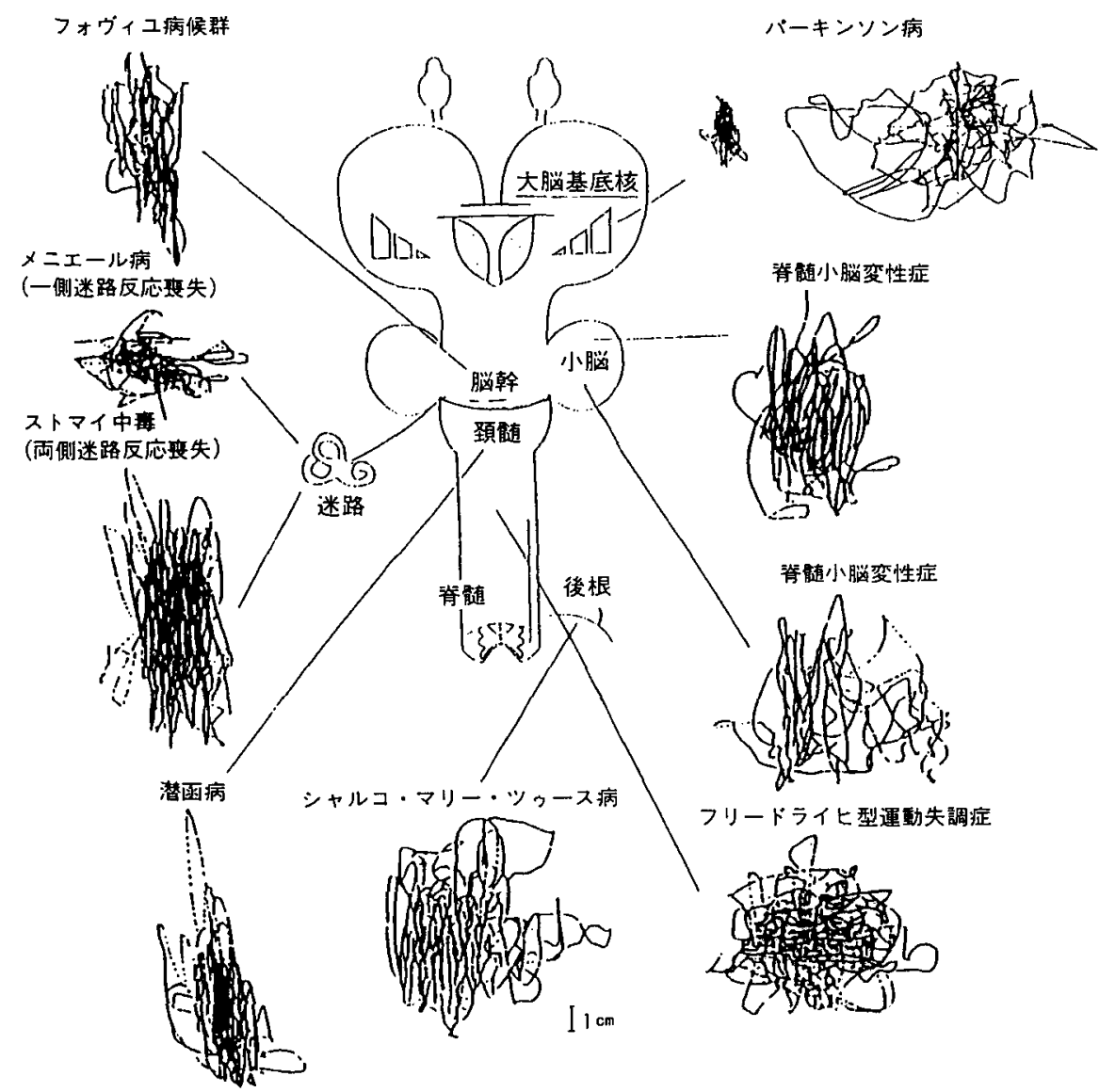

図11 各種平衡障害例の重心動摇パターン（時田 喬, 199511)

振の検査では非注視下の条件が大切であり， Frenzel 眼鏡の装着が望ましい。自発眼振がみら れる場合はめまいが存続し，しかも，めまい発作 中ないし発作直後の病態を示惨している。頭位眼 振検查では仰臥位で行い, その後, 頭位変換眼振 に移行できるので，若干，時間も掛かるが座位の 頭位眼振検査より診断が確かとなる。一般的にみ て末梢性疾患では定方向性の回旋成分を伴った水 平性の自発眼振や頭位眼振を認め, 頭位变換眼振 では回旋性の要素を伴う垂直回旋混合型の眼振が 認められ，中枢性病変では方向不定の水平性眼振 を示すことが多く，また，垂直性眼振，斜行性眼 振の発現があれば中枢性疾患と考えて差し支えな い。

頭振り眼振検査は簡便で，その誘発率も高く優 机たスクリーニング検查といえる。筆者は水平力
向と矢状方向にそれぞれ20回頭振りを行って Frenzel 眼鏡下で観察しているが，垂直性眼振の

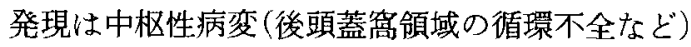
に多い。

その他, 眼振以外の異常眼運動の発現にも留意 すべきで, 異常自発眼運動の存在そのものが病巣 局在診断に役立つことが多い(図12)。

外来に和けるめまい検查としては時間的制約も あるので前述の手順まででめまい疾患の診断は大 体に打いて推定が可能になると考えられる。

さらに，精密な検査が必要である時は，例えば 視運動性眼振検查や space taking lesin を疑う症 例では頭部の CT, MRI などの画像検査を病院に 依頼紹介すべきであうう。

視運動性眼振検查の診断的意義は高いが外来に 抢ける簡便な検查法として高価な装置がなくても 


\begin{tabular}{|c|c|c|c|}
\hline \multicolumn{3}{|c|}{ 障害部位 } & 異常眼通而 \\
\hline \multirow[t]{3}{*}{ 脱 } & & 脸 & 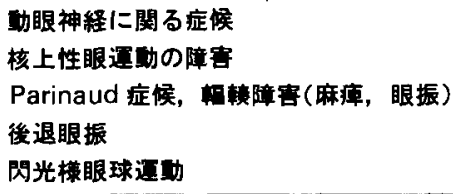 \\
\hline & 柢 & & $\begin{array}{l}\text { 偍側への井同偏視，患側への注視障富 } \\
\text { 左右側方注視眼振 } \\
\text { MLF 症侯 } \\
\text { Ocular bobbing }\end{array}$ \\
\hline & 延 & 髄 & 回旋性眼振，see-saw 眼振 \\
\hline \multirow{2}{*}{$\begin{array}{l}\text { 小 } \\
\text { 脳 }\end{array}$} & 半 & 球 & $\begin{array}{l}\text { opsoclonus } \\
\text { flutter-like oscillation } \\
\text { rebound nystagmus } \\
\text { dysmetria,saccadic pursuit }\end{array}$ \\
\hline & & 部 & $\begin{array}{l}\text { 自発性下眼䁐向き垂直眼振 } \\
\text { 垂直性頭位変換眼振 }\end{array}$ \\
\hline
\end{tabular}

図12 局在病巣 (障害部位) と異常眼運動

巻尺の目盛を眼前の右あるいは左に引き出して目 盛を移動させ，発来する視性眼運動を定性的にチ ェックすることも可能である。筆者はめまい症例 の対応には病歴聴取 $\rightarrow$ 局所診察 $\rightarrow$ 神経学的検查 $\rightarrow$ 眼球運動の観察（眼振を含む） ）重心動摇検査ま でを約15～20分程度で済ませている。眼振の検査 には ENGの使用は客観性の評価之記録保持のた めに大きな利点のあることは論を俟たないが，回

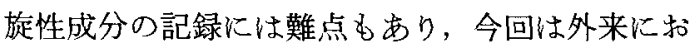
ける実地的な検查法としての眼振検査は Frenzel 眼鏡下での裸眼観察でも十分に役割りを果たすこ とを述べた。その他，めまいの全身的検查として 血液生化学的検查や生理学的検査などもあるが， 近年の人口動態から高老年層の増加に伴い, 高血 圧症, 動脈硬化症や，高脂血症などの背景因子が 血流障害を引き起こし，めまいを発来することも 考慮し, 血液生化学的検查, なかでも赤血球, 一 マトクリット，血小板凝集能，フィブリノーゲン 値あるいは総コレステロール，及ーリポ蛋白，中性 脂肪, 遊離脂肪酸, 燐脂質, HDLなど血清脂質 の測定も大切である。

\section{ポイントN}

診断

症例の提示

Case 1 突発性難聴に伴らめまい
27歳, 男性, 会社員

2 日前の早朝, 起きたとき右耳の閉塞感, 耳 鳴, 回転性めまいがあり, 悪心, 嘔吐もあった。 家人との対話で右耳の遠いことに気付いた。来院 時の右聴力は $60 \sim 70 \mathrm{~dB}$ の水平型感音難聴を示 し, 自発眼振検査で左向き水平・回旋混合型の眼 振が認められた。随伴症状としての神経学的所見 は認められず, 右突発性難聴と判断し来院時, 直 らにステロイドを含んだ点滴療法を行い，翌日は 大学病院に受診する上ら指示し紹介した。

この症例ではめまいと耳鳴があり，高度の一側 性難聴がみられたが，脳神経症状や小脳症状の所 見もなく，末梢性めまい疾患之考光られ，とくに 発症の難聴が突発的であり他に誘因も見当らない ことから突発性難聴に伴っためむい症と考光, 大 学病院に紹介し，幸いにも聴力が改善した例であ る。

Case 2 左メニエール病

34歳, 女性, 主婦

数年前からめまいを訴兄, 同時に左耳の閉塞 感, 耳鳴を感じ, めまいは $2 \sim 3$ 時間持続し，そ の後軽快し, 蝸牛症状も減弱するといった回転性 めまい発作をこれまでに 4 〜回経験している が，ここ 1 週間前上りめまい感が強く，頭重感， 体の不安感もあるので来院した。

局所所見には異常なく, 神経学的徵候もみられ ないが血圧 $102 / 63 \mathrm{mmHg}$, 自発眼振はみられな いが，頭振り眼振化て左向き水平 - 回旋性眼振を 発来し, 聴力検査では左側の低中音域に $30 \sim 40$ $\mathrm{dB}$ の感音難聴を示した。家族構成のうち祖母が 在宅し軽度の痴呆性にて介助の必要があり，長男 の中学受験を控えているなどの心因的なストレス む見受けられた。この症例は耳鳴, 難聴, めない があり，しかも，めまい発作時には耳閉塞感，耳 鳴などの蝸牛症状の悪化がみられた典型的なメ二 エール病であるが背景因子としてストレスが関わ っていると思われたので, 内服療法と併せ精神神 経科医との連携を保ち加療を行いつつ軽快に向か った。

Case 3 起立性低血圧症によるめまい症

22歳, 女性, 会社員

5〜6歳頃から立らくらみがあり, 中学〜高校 生の頃にもめまい感と体の横摇れや，急に立つ之 ボッとして気分が悪くなったり朝の起床がつらい 
などの訴党がありこの $2 \sim 3$ カ月前から同様の 症状が強くなり大学病院を含め $2 \sim 3$ の病院を受 診したが軽快せず，知人の眼科医（患者の親族） より紹介来院した。来院時, 顔面蒼白で無気力,

偏頭痛も訴えていた。

局所所見, 神経学的所見に異常なく, 血圧 106/ $58 \mathrm{mmHg}$, 手足がやや冷たく感ぜられた。眼球 運動検查にても眼振らしい所見は得られなかった が，頭位変換時に気持ちが悪くなり軽度の悪心を 伴った。Schellong test では起立時血圧下降は 18 $\mathrm{mmHg}$ で境界域を示したが起立性失調症状がみ られ，眼科的な検查では眼底血圧も起立時の降下 傾向があり起立性低血圧によるめむい症と診断し た。昇王剤と併せ循環改善剤の投与を続け，治療 約 6 力月後には自覚的にもほほ正常化し, 日常生 活も復してきた。

Case 4 中年層化及らるるまい症

51 歳, 女性, 会社員

来院 1 週間前より立ちくらみがあり，3 日前の 昼食後, 急に立ち上がった時にめまい感が数秒あ り, 坐っていても持続し, 間もなく治ったが夕方 の㷌途，体の不安定と歩行がぎこちないことを感 じた。

来院時は血圧は 106/72 $\mathrm{mmHg}$ とやや低く, 気 分不快と軽度の悪心があったが，神経学的徵候も なく, 眼球運動も smoothであり, 頭位眼振検査 および頭振り眼振検查で垂直性成分がみられた。 立ち直り反射では Mann 検査で不安定を認めた。 誘因としてはこの 1 力月間, 仕事量が多く, 睡眠 時間も短く, 疲れ気味であった。来院時は点滴療 法を行い，併せて内服を投与し 2 日後には自覚的 にも改善し，5日後には気分も良好となり，歩行 も正常となったが，血幵は 100/42 mmHg であっ た。本例は低血圧を伴った後頭蓋窩領域の脳循環 不全と考えられるもので約 1 力月間の内服療法で 自覚症状は殆ど軽快したが，休薬するとめまい感 を若干訴えるとのことであったので，その後 2 カ 月間の服薬をすすめ改善に至った。

Case 5 高年層にみられるめまい症 66歳, 女性, 主婦

約10年前頃からめまいを訴え，悪心もあり，こ れまでにも近医も含め数力所の病院を受診したが 軽快に至らず，1 月月前頃から急に起き上がる時 にめまい感が強くなり,今回, 紹介来院した。初

\section{STATOKIMESIGRAM (CLOSE)}
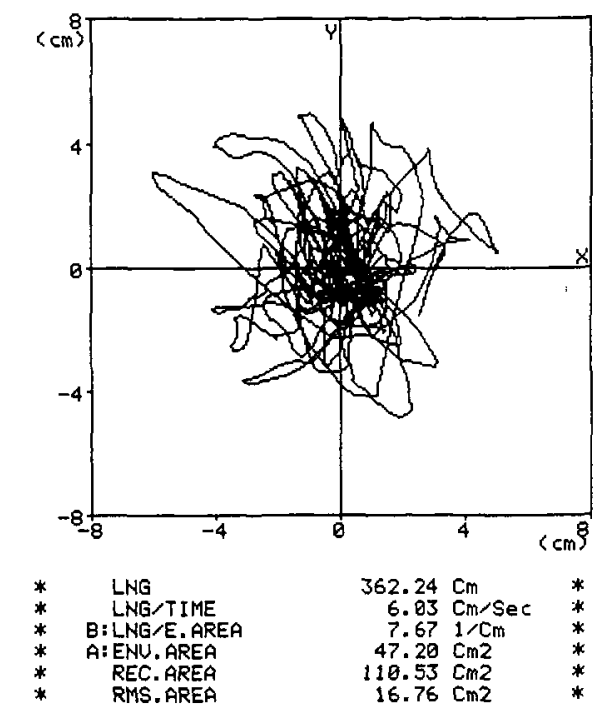

EWALபAT I OH (GRAUICHART)

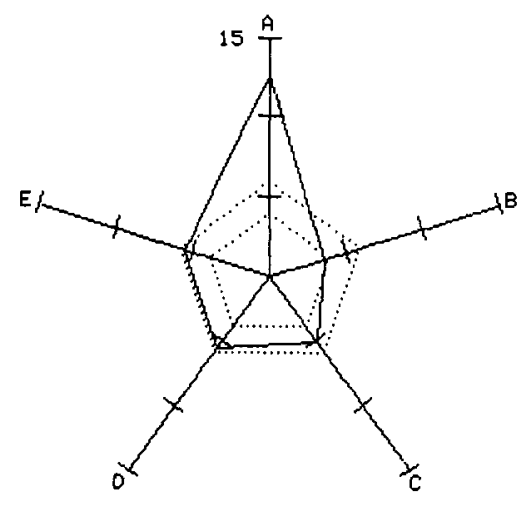

図13a 治療前

診時, 神経学的症状もないが頭振り眼振検查で右 向き水平性眼振がみられ，偏頭痛す訴えていた。 血圧は $156 / 90 \mathrm{mmHg}$, 重心動摇検査でびまん型 の動摇パターンを示し, 面積も増大していた（図 $13 \mathrm{a})$ 。この例は脳動脈硬化 $\rightarrow$ 脳循環不全と考光脳 代謝改善薬の投与を約 2 力月間行的たら，自覚的 にめまい感も消失し眼振もなく，重心動摇検査で は改善を示した（図13b)。

$$
\text { ポイント V }
$$

治療

一般の実地臨床医にとってのめまい治療は薬物 療法が主流であるう（図14）。めまい恰査におい 

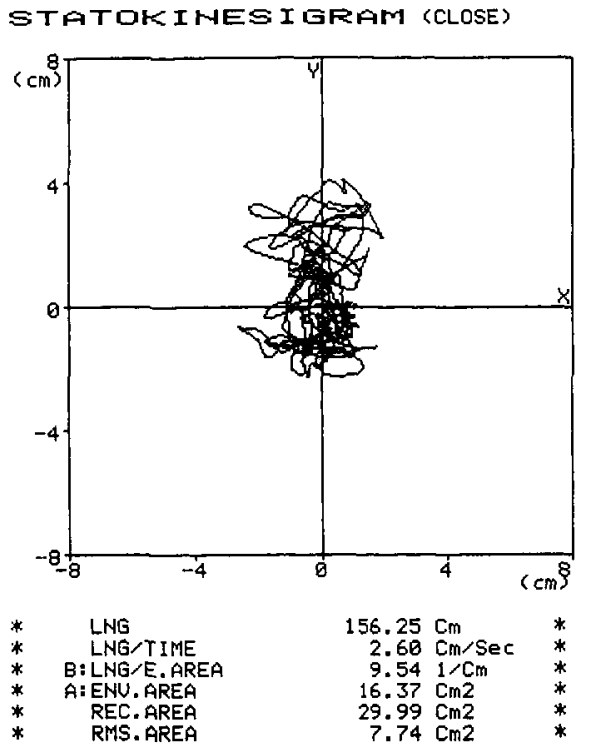

EUALUAT I DH (GRAUICHART)

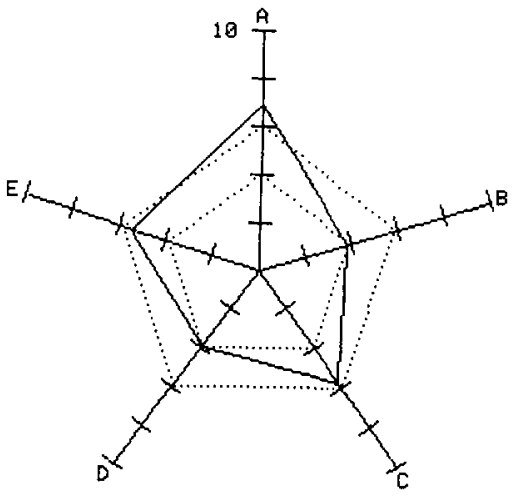

图13b 治療後

て中枢性病変, 中でも space taking lesion と考 克られる腫鈞あるいは变性疾患が疑われたら專門 病院への紹介を計るべさである。末梢性疾患の中 でもメニェール病と診断され，保存療法で改善が 得られずめまい発作が頻繁で, 聴力障害が悪化㑯 向を示す症例には内リンパ減荷術が鹰められる。 これらを除外すればめまいの背景因子を考慮しな がら保存的な薬物療法で効果が得られる。めまい の発生には末梢領域であれ，中枢領域であっても 血流の偱環不全に基づく場合が多いことからめま い剤（表 1) に併せて血管拡張剂（表 2)，ある いは脳代謝改善剂（表 3）の投与が-般的である ら。また，めいに伴う悪心，嘔吐，不安感に対

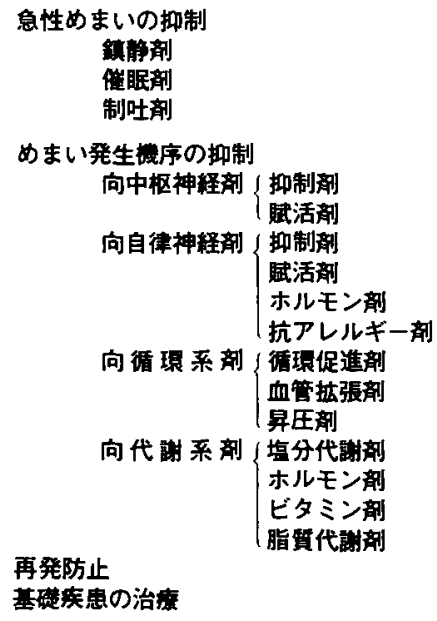

图14 薬物療法

表 |めまい薬

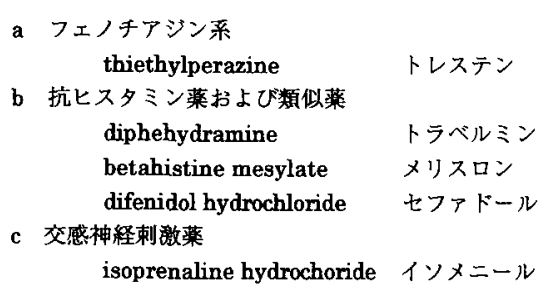

(今日の治療薬'95: 水島 裕編 ${ }^{2}$ )

しては適宜制叶剤の投与や精神安定剤の使用も大 切である。

処方例の提示

1. メニェール病症例に対して

メニエール病の病態が内リンパ水腫であること を考光，発作寛解のために脱水効果のある利尿剤 の投与む行っている。
a. $\operatorname{Rp} 1$ イソパイド
$60 \sim 90 \mathrm{ml}$
$3 \times$
2 メリスロン
$3 \sim 6$ 錠
トレンタール
$3 \sim 6$ 錠
カピラン $(100)$
$3 \sim 6$ 錠
メチコバール
(250)
$3 \sim 6$ 錠
$3 \times$
3 七ルシン (2)
1 錠
就寝前 $1 \times$
b. $\mathrm{Rp}$ メリスロン
$3 \sim 6$ 錠
カルナクリン
(50) 
表 2 血管执張剤

\section{L 血管・骨筋系に直接作用する菜詴}
a. パパベリン系薬
cyclandelate
cinnarizine
カピラン
dilazep hydrochloride
difenidol hydrochloride
b、 ニコチン酸系菜
nicotinic acid
inositol hexanicotinate
c. ビタミン $\mathrm{E}$ 系薬
tocopherol acetate
d. Ca 楛抗菜
nicardipine
アプラクタン
コメリアン
セファドール
ナイタリン
ヘクサニシット
ユベラ
ペルジピン

\section{II. 神紾作動性血管拡張菜}
a. $\alpha$-受容体抑制菜
tolazoline hydrochoride
b. $\beta-$ 受容体興著薬
isoxsuprine hydrochloride ズファジラン
c. 血管運動中枢抑制薬
vinpocetine
カラン
II. 循粠系ホルモン都
1. kallidinogenase kallikrein
サークレチン,カルナクリン
カリクレイン
IV 末梢循㻴改善薬（脳循環を含む）
pentoxifylline
トレンタール

(今日の治療薬'95：水島 裕編 $^{2}$ )

表 3 脳代謝改善剤

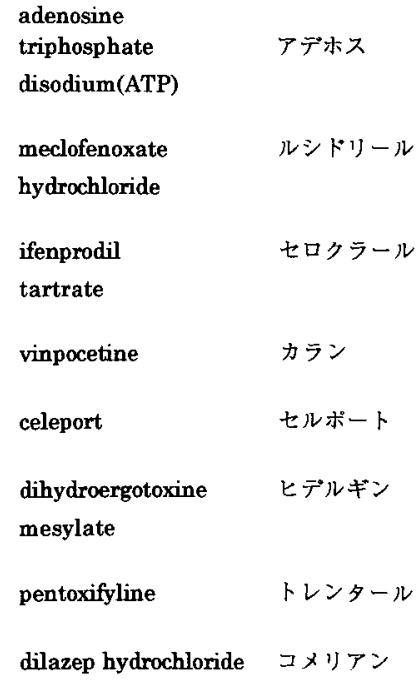

(今日の治療薬”95：水島 裕編 2 )

$$
\begin{array}{ll}
\text { アデホス }(30) & 3 \sim 6 \text { 錠 } \\
\text { トレンタール (100) } & 3 \sim 6 \text { 錠 } \\
3 \times &
\end{array}
$$

急性期の発作で内服が困難な場合には点滴療法 を行う。

$$
\begin{array}{rr}
\text { 点滴 フルクトラクト } & 200 \sim 500 \mathrm{ml} \\
\text { メイロン } & 60 \sim 100 \mathrm{ml} \\
\text { ナイクリン } & 20 \sim 60 \mathrm{ml} \\
\text { プレドニン } & 30 \sim 60 \mathrm{mg} \\
\text { セルシン } & 5 \mathrm{mg}
\end{array}
$$

2.末梢性めまい症に対して

中枢性所見もなく，末梢性めまいと考元られる めまい症全般に対してはメニエール病例と汪注同 様であるが，発症素因として自律神経不安定を伴 ら症例やめまいと偏頭痛あるいは耳鳴がある症例 には，そ抗ぞれに適した薬荗す使用している。

\section{処方例 1}

$$
\begin{aligned}
& 1 \text { メリスロン } \\
& 3 \sim 6 \text { 錠 } \\
& \text { イソメ = ル } \\
& 3 \sim 6 \text { 錠 } \\
& \text { アデホス (20) } \\
& 3 \sim 6 \text { 錠 } \\
& \text { トレンタール } \\
& 3 \sim 6 \text { 錠 } \\
& 3 \times \\
& 2 \text { セルシン }(2 \mathrm{mg})
\end{aligned}
$$

処方例 2

$$
\begin{aligned}
& \text { カルナクリン }(50) \\
& \text { トレンタール } \\
& \text { カピラン }(100) \\
& \text { メチュバール }(250) \\
& \quad 3 \times
\end{aligned}
$$$$
3 \text { 錠 }
$$$$
3 \sim 6 \text { 錠 }
$$$$
3 \text { 錠 }
$$$$
3 \text { 錠 }
$$

3.動脈硬化症などによる脳循環不全症に対し $\tau$

近年の人口動態により中高年層が増加し，めま いを訴えるケースが多い。

脳梗塞後遺症と考兄られる症例にも度々遭遇す る。急激な体動や起立時, 前屈, 後屈などの際に 瞬間的なめむい感，眼前暗黒感を訴えることが多 く，時に手足のシビレ感もあり，体の不安定感を 訴えることもみられるが意識障害はなく，麻痖症 状も殆どなく，機能的循環不全と考えられる症例 
が多い。

処方例 1

\begin{tabular}{|c|c|}
\hline \multicolumn{2}{|l|}{ セレポート } \\
\hline トレンタール & 3 錠 \\
\hline カラン & \\
\hline \multicolumn{2}{|l|}{ ヒデルギン $(1 \sim 2 \mathrm{mg})$} \\
\hline \multicolumn{2}{|l|}{ 高血圧を伴ら症例 } \\
\hline ペルジピン $(10 \sim 20 \mathrm{mg}$ & \\
\hline \multicolumn{2}{|l|}{ いずれか } \\
\hline \multicolumn{2}{|l|}{ あるいは } \\
\hline ルシドリール (100) & 3 錠[外傷既往例 \\
\hline
\end{tabular}

処方例 2

$$
\begin{array}{r}
\text { セレポート } \\
\text { カルナクリン } \\
\text { トレンタール } \\
\text { セロクラール } \\
3 \times
\end{array}
$$

その他, 糖尿病, 高脂血症, 血小板凝集能六進 症など背景要素があり，動脈硬化症を来し，脳循 環不全病態が考学られる症例にはそれぞれの背景 を考慮した治療が合理的である。

処方例 1

$$
\begin{gathered}
\text { コレキサミン }(200) \\
\operatorname{MDS}(150) \\
\text { ユベラニコチネート } \\
\text { トレンタール } \\
3 \times
\end{gathered}
$$

3 錠 3 錠

処方例 2

$$
\begin{aligned}
& \text { カピラン } \\
& \text { あるいは } \\
& \text { アプラクタン }(50) \\
& \text { トレンタール } \\
& \text { パナルジン } \\
& \quad 3 \times
\end{aligned}
$$

内服投与に上りめまいないし，めまい感は軽快 傾向を示すが自覚症状のみならず他覚的所見の改 善にもチェックし, 少なくとも 3 カ月間の保存療

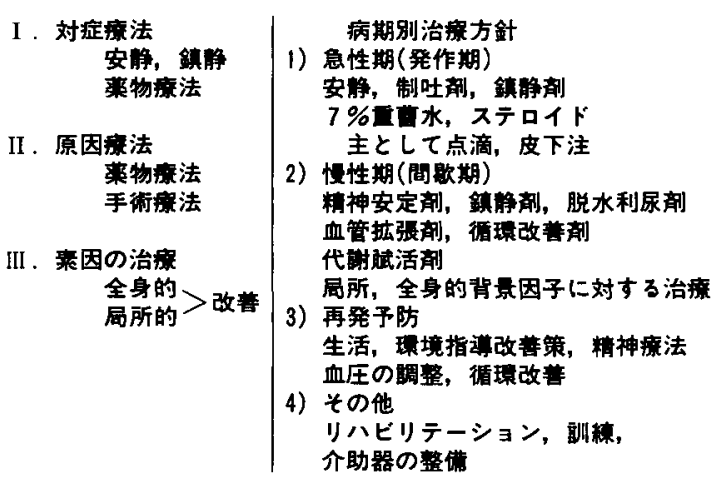

図15 治療

法は大切である。短期間の治療により再発あるい は再然を繰り返すことも多いので, 日常生活の指 導や食事療法と併せた中〜長期の治療を心掛ける べきである5（図15）。

\section{おわりに}

めまい症例は耳鼻科医がその対応に当たること の大切さを基本にして診断・治療のポイントを略 述した。診断の中でも病歴聴取が大きな役割を占 め, 次いで神経学的徵候の有無により末梢性めま いか中权性めまいかに振り分けられる。生命に重 篤な疾患（脳幹〜小脳出血，〈も膜下出血など） は一般診療所に訪れることは殆どないが，これら を除き必要に応じて関連他科（脳神経外科，眼 科, 精神神経科) との連携を保ちながら腫瘍性病 変や变性疾患はその専門領域に紹介し, 典型的な 内耳性病変をはじめ中高年層に多いめまい症にも 耳鼻科医が取り組むことを期待したい。

\section{文献}

1) 時田 喬: 重心動摇検査一その実際々解釈 一. ア $=マ$ (株), 1995

2 ）今日の治療薬' $95:$ 水島 裕編

$$
\left(\begin{array}{l}
\text { 原稿到着: 平成 } 9 \text { 年 } 1 \text { 月 } 13 \text { 日 } \\
\text { 別刷請求先 : 竹山 勇 } \\
\text { T194 東京都町田市つくし野2-10-32 }
\end{array}\right)
$$

